\title{
Some Remarks About the Graeae (Graiai)
}

\author{
Juan S. Gómez-Jeria
}

\begin{abstract}
The center of the present work is the encounter of the Indo-European hero Perseus with the Graeae. Some comments about the end of the Bronze Age are offered together with the thesis that Perseus was a real human being. A description of the Graeae, based on early Greek texts and pictorial representations, is presented. Several new questions about these enigmatic figures are presented. Who had this idea first? Why are they called "horror", "waster of cities, "alarm"? Why they shared one eye and one tooth? Why were they only two at the beginning? Why does their number increase to three? Why they were forced to release information making both temporarily blind at the same time? Some provisory answers are provided and discussed.
\end{abstract}

Index Terms-Bronze Age, Dark Age, Graeae, Heroic Age, Mycenae, Perseus.

\section{INTRODUCTION}

Perseus (The Destroyer) was the legendary founder of Mycenae and one of the three greatest Greek heroes before the time of Hercules (with Cadmus, founder and first King of Thebes and Bellerophon, son of Glaucus, King of Corinth). Circa 1290 BCE Perseus leaves Argos after the death of King Acrisius. He rebuilds then the walls of Mycenae (it is in this sense that Perseus is considered as being the founder). This places Perseus at a time when the Mycenaean palatial civilization was coming to an end, or ended, and the Greek Dark Age was beginning (c. $1200 \mathrm{BCE}-c .800 \mathrm{BCE})$. This date agrees with data showing that circa $1300 \mathrm{BCE}$ the first palace at Mycenae was destroyed and repaired, the Lion Gate was added and the fortifications extended (it is interesting to notice that it was believed that the Cyclopes built the "cyclopean" fortifications at Tiryns and Mycenae. This is a very strong indication of the magnitude of the disaster and the subsequent decadence or a signal of the arrival of new northern peoples that had never before seen such a kind of buildings). The Linear B writing of the Greek language used by Mycenaean bureaucrats ceased to be employed. A new Greek alphabet, derived from the earlier Phoenician alphabet, began to be used since the late 9th century BCE or early 8th century BCE. The oldest examples of this new way of writing are the Dipylon inscription (c. $740 \mathrm{BCE}$ ) and the three-line inscription on the Cup of Nestor (found in Pithekoussai, dated c. $730 \mathrm{BCE}$ ).

The reader will notice that I am considering Perseus as a real living human. The refoundation of Mycenae, and perhaps other similar achievements made Perseus known in a wide area of Greece, and are probably the basis of his incorporation

Juan S. Gómez-Jeria, Faculty of Sciences, University of Chile, Santiago, RM, Chile, (56) 2-29787371 as the hero of a Journey. Between the widespread collapse of the Bronze Age civilization and the use of the new Greek alphabet, the knowledge of historical facts was preserved and transmitted orally from one generation to another with all the problems that this form of communication has. The fact that until today we have no archeological evidence of his existence is not a sufficient argument to throw him into the bag of nonexistent beings as many have done. I must remind the reader that when all specialists agreed that 12,000 years ago our ancestors were only hunter-gatherers, the spectacular ruins of Göbekli Tepe were found, with their ritual (?) use dating back to the $10^{\text {th }}$ millennium BCE. If we give the benefit of the doubt to Perseus and other heroes as being real humans we open a door to new questions and problems. In his Against the Method, Paul Feyerabend says this: "I prefer more paradoxical formulations, however, for nothing dulls the mind as thoroughly as hearing familiar words and slogans". This should be the natural attitude for various kinds of studies and analysis.

The chaos at the end of the Bronze Age, never seen or experienced before, is probably the only reason why Hesiod introduced in his Works and Days the Heroic Age between the Bronze Age and the Iron Age (the Heroic Age is not associated with any metal, like the other four are, and this is an obvious anomaly). I cite ${ }^{[1]}$ :

Et, sous la main du dieu, pour ce siècle d'airain,

Naquit des flancs du frêne un nouveau genre humain.

Mais Mars revendiqua pour l'oeuvre de la guerre

De ces rudes mortels la race sanguinaire.

Leur corps qui renfermait un coeur de diamant

Ne se refaisait point par un vain aliment,

Et leurs bras vigoureux dans leur forte structure

Supportaient, sans fléchir, le poids de leur armure.

Ils n'avaient pas le fer, mais l'airain non moins dur

Fournissait à leur main un tranchant aussi sûr,

Et, s'unissant aux airs pour protéger leur tête,

De leurs abris grossiers il soutenait le faîte.

A la fin, possédés de l'ardeur des combats,

Ils ont, en le bravant, appelé le trépas;

Leur race, qu'épuisait son aveugle courage,

En foule des enfers aborda le rivage,

Et, pour jamais, des morts le sombre et froid séjour

La ravit tout entière à la clarté du jour.

Cependant, quand la terre en ses profonds abîmes

Eut de cet âge impie enseveli les crimes,

Jupiter enfanta ces immortels héros

Aux suprêmes honneurs promis par leurs travaux,

Et des champs, que souillaient une autre race humaine,

Pour le purifier leur livra le domaine.

Guerriers et des combats tentant aussi le sort,

En se couvrant de gloire, ils trouvèrent la mort.

Les uns, des fils d'OEdipe embrassant la querelle, 
Ont payé de leur sang la haine fraternelle;

Pour reprendre à Pâris, Hélène aux blonds cheveux,

Les autres ont franchi l'Océan orageux,

Et transportant la guerre aux champs de la Phrygie,

Au milieu des combats ils ont laissé la vie.

Un dieu les appela loin des séjours humains,

Sous les lois de Saturne, à d'immortels destins.

Là coulent des héros les paisibles journées,

Dans les riants bosquets des îles Fortunées,

Où l'arbre, trois fois l'an, se couronne de fleurs

Et prodigue ses fruits aux aimables saveurs.

Around $700 \mathrm{BCE}$, the legend of Perseus was perhaps the most widely known Greek myth as far as we know. For me it is totally clear (i.e., I believe that) that Perseus' story began to be put together at an unknown date (after 1290 BCE), possibly in visual forms (see for example, Louvre Museum, Cat. number CA795, circa $660 \mathrm{BCE}$, from Thebes) and transmitted in oral form until Hesiod's time. The steps leading to what can be called the fixed or final form are still not known (I am optimistic in this regard). On another hand, perhaps we will never be able to fully understand this history simply because our mind has evolved in the last 3,300 years and is today qualitatively different (do not confuse with superior) from the mind(s) of ancient Greeks. Before writing what follows I must say that I read a really large number of papers and books (including the works of Hartland ${ }^{[2]}$ ) but I will not cite them all. In the last part of the $19^{\text {th }}$ and the beginning of the $20^{\text {th }}$ century it was customary to write beautiful and interesting books filled with useful references and comments. Today, with an enormous number of useless books covering all conceivable topics, I consider that citing too many references without a specific need is only pedantry. As I am sure that the readers of this note are well acquainted with Perseus' odyssey, I will not repeat it here. My interest is in the step where our hero obtains the information allowing him to find the Hesperides: his encounter with the Graeae. During my bibliographic research I found a very interesting and helpful paper by Lawrence Parmly Brown about the Cosmic Teeth ${ }^{[3]}$. I do not share his lunar interpretation of the Graeae, but his work served as a source of new inspiration and gave me the final idea of what I needed to comment on.

\section{THE GRAEAE}

The Graeae were called this way because they were gray (i.e., gray-haired) from their birth (alternatively spelled Graiai and Graiae). They were sisters who shared one eye and one tooth among them. Their names were Deino (or Dino, “dread"), Enyo ("horror", "waster of cities"), and Pemphredo (or Pephredo, "alarm", "wasp" see below). They were daughters of the incestuous union of the sea gods Phorcys and Ceto, and sisters of the Gorgons.

The earliest known allusion to the Graeae is found in Hesiod's Theogony (v. 270, ${ }^{[4]}$ ): "Then to Phorcys Ceto bore beautiful-cheeked old women, gray-haired from their birth, whom both the immortal gods and human beings who walk on the earth call the Graeae, fair-robed Pephrēdo, and saffron-robed Enyō, and the Gorgons who dwell beyond glorious Ocean at the edge towards the night, where the clear-voiced Hesperides are, Sthenno and Euryale, and
Medusa who suffered woes". Hesiod does not mention the eye and tooth they share and says that there the Graeae were only two ${ }^{[4]}$. Hesiod was active between 750 and $650 \mathrm{BCE}$. Cora Angier analyzes the amount of repetition in the Theogony of Hesiod stating the following: "such repetition could often, doubtless, be random and meaningless in the hands of a less skillful singer, but when used by an organizing and classifying mind such as that of Hesiod it contributes greatly to the over-all organization of the poem" "5]. On the basis of Angier's analysis we may conclude that at Hesiod's time the Graeae were undoubtedly two.

Circa 470 BCE Aeschylus mentions the Graeae in his Prometheus Bound (v. 790-797, ${ }^{[6]}$ ): “...crossing the roaring sea, till thou art come unto the Gorgon plains of Kisthene, where Phorkis' daughters dwell, three ancient maidens, swan-shaped, having one eye for all, with but one tooth, whom neither sun looks on with his rays nor ever moon by $n i g h t$ ". Aeschylus does not give their names but we learn that now the Graeae are three.

The Pseudo-Apollodorus, in his Bibliotheca (Lib. II, 4, 1-2, dated to the first or second century, $\left.{ }^{[7]}\right)$, narrates the following: "So under the guidance of Hermes and Athena he made his way to the daughters of Phorcus, to wit, Enyo, Pephredo, and Dino; for Phorcus had them by Ceto, and they were sisters of the Gorgons, and old women from their birth. The three had but one eye and one tooth, and these they passed to each other in turn. Perseus got possession of the eye and the tooth, and when they asked them back, he said he would give them up if they would show him the way to the nymphs.... When the Phorcides had shown him the way, he gave them back the tooth and the eye, and coming the nymphs got what he wanted".

A search inside some old French texts provided three interesting results. In the first one, Philostrate of Lemnos ( $c$. 190 - c. 230) relates the following: "car Perseus, estant arrivé aux Gorgones, surprit d'arriuée Pephredo, \& Enyo, deux des sours, \& leur osta l'œil \& la dent don't elles se seruoyent l'une aupres l'autre á tour de roolle, n'en ayant qu'un seul; \& ne leur voulut rendre qu'elles ne l'eussent

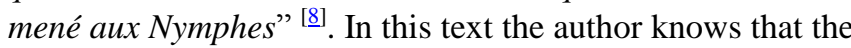
Graeae were three but he seems not to know the name of the third. This text is somewhat confusing. Conti tells this regarding the genealogy of the Graiai: "De Phorque, Tetoa, Phorcides, Pamphede, Enyo \& Chersis au lieu de laquelle quelques-vns veulent que ce soit Dino" $\left[{ }^{9}, \underline{10]}\right.$. We note here that at that time the author remarks that the name of one of the Graeae was not just one ${ }^{[10]}$. Juigné Broissinière says this in his Dictionary: "Graes furent trois soeurs filles de Phorcys, ainsi appelées du Grec, comme qui diroit Chenues; elles n'auoient qu'vn oeil \& vne dent don't elles se seruoient á tour, Persée s'en seruit pour aller deffaire les Gorgones auec lesquelles quelques vns les confondent" [11]. Philostrate of Lemnos seems to suggest the fact that the use of the eye and the tooth was simultaneous. For more literary mentions of the Graeae, see Ogden $\stackrel{[10]}{ }$.

\section{REPRESENTATIONS OF THE GRAiAE}

Figure 1 shows one of the Graiai (fragment, Delos, 
World Journal of Research and Review (WJRR) ISSN:2455-3956, Volume-4, Issue-3, March 2017 Pages 42-46

Archaeological Museum. Vase number 214261, dated between $475 \mathrm{BCE}$ and $425 \mathrm{BCE}$ ).

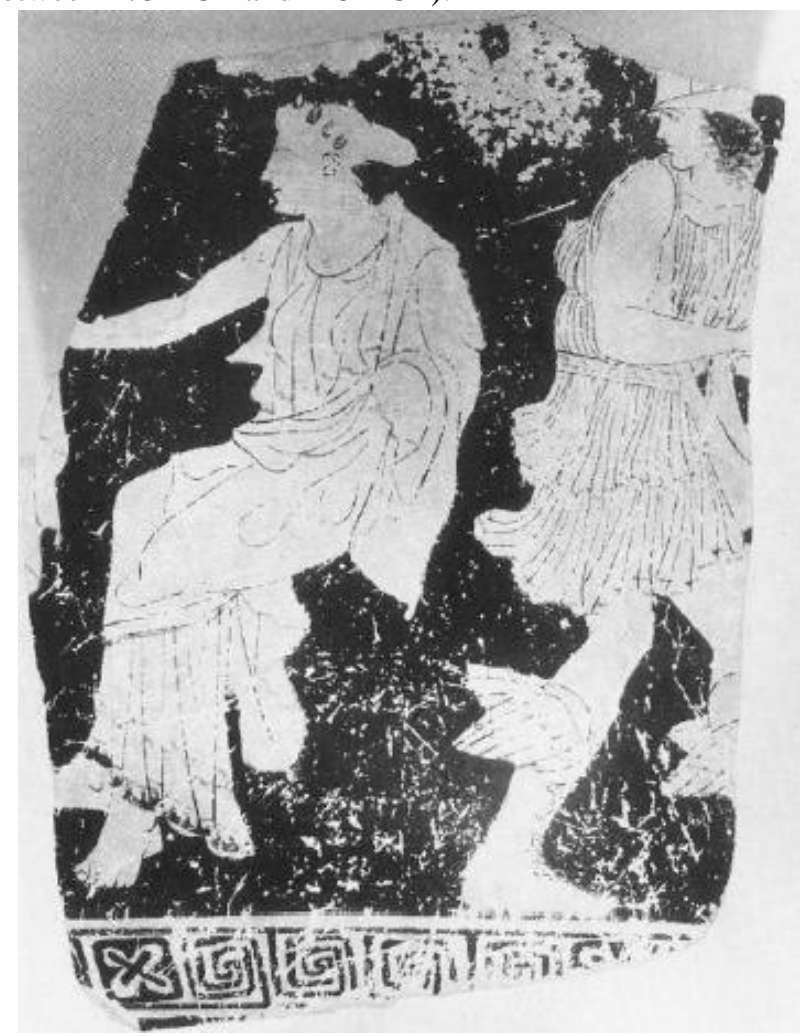

Figure 1. One of the Graiai.

John Oakley interprets this fragment as follows: "Perseus on the right sneaking off with cupped hands, looking round. On the left sits one of the Graiai who faces left, reaching out with the right hand for the eye. Her hair is indicated in reserve as the Graiai on the Metaponto krater, and she is also blind" [12]. John Beazley says this: "To the left of our Perseus a woman sits on a rock, her lips slightly parted, her right arm extended, her left arm wrapped in her himation, her back turned toward Perseus. To left of her is another figure, also seated on a rock: part of the himation remains (intelligible by comparison with the corresponding parts of the other himation), and a white line indicating the rock-seat. The first woman wears, under her himation, a sleeveless garment of thick material. She has a necklace, and a wreath, probably of metal leaves. The contour of the hair is given, but there is no indication of hair within the contour: white hair therefore whether it was left in the native hue of the clay, or, as is more probable, the white colour has disappeared, leaving no trace beyond a difference of surface - matt instead of lustrous imperceptible in the photograph. The eye is not indicated: in its place there is a light brown oval stain (possibly with a darker horizontal line near the top, but this is not certain from the photograph): it is a blind eye - closed lids, sunk in the socket.... Here Perseus has seized the eye and stolen away. Unaware of what has happened the Graia whom we see still holds out her hand expecting to receive the eye in her turn" [13].

I found another representation of the Graeae (cited by Brown, ${ }^{[3]}$ ) in the old Castellani Collection: "Miroir étrusque: Visite de Persée chez le Grées. A gauche, Enyo (Ennie), drapée, assise, tenant un miroir et remettant son oeil à Persée (Phersé), qui avance la main droite pour le prendre, en même temps qu'il s'empare de la dent qui lui présente Pephredo
(Pemphetru)". I found another description of this object in the Catalogue of the Castellani collection, in the loan exhibition of the Metropolitan Museum of Art, New York, 1877: "Representation of Perseus, accompanied by Minerva, stretching out his hand to take the eye from the Graeae. The names of the personages are written beside them in the Etruscan characters". After a really long search, I found the image shown in Fig. 2 (from ${ }^{[14]}$, enhanced with Helicon Filter software).

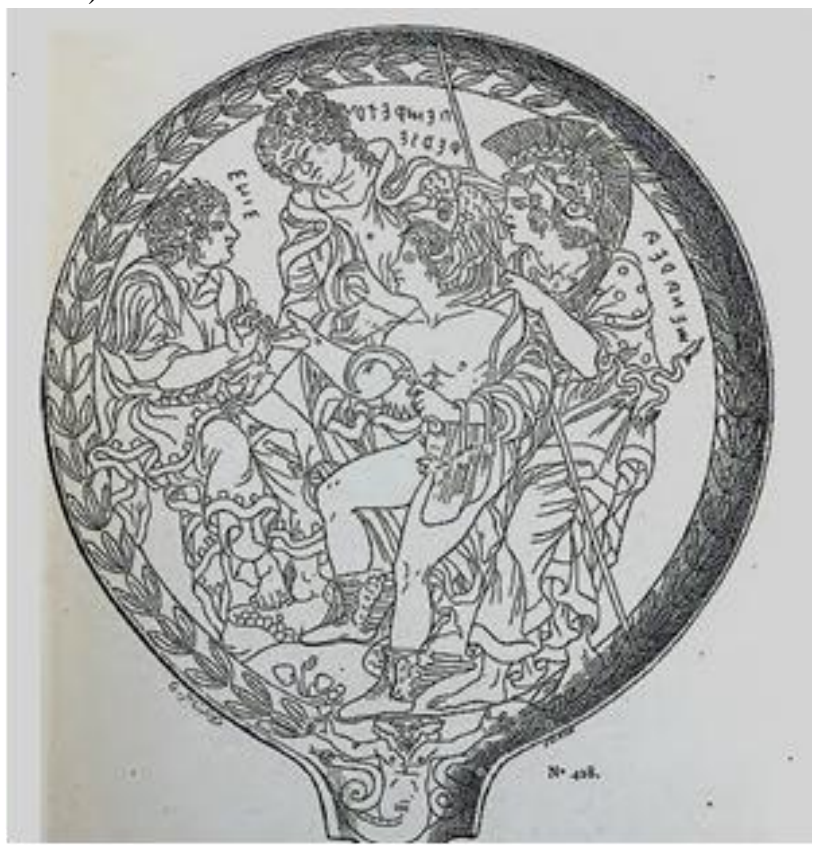

Figure 2. Etruscan mirror from the original Castellani Collection (see below).

A second search produced the photo of the original Etruscan mirror (enhanced with Helicon Filter software) shown in Fig. 3. This object is now in The Metropolitan Museum of Art of New York (Accession Number: 26.60.63).

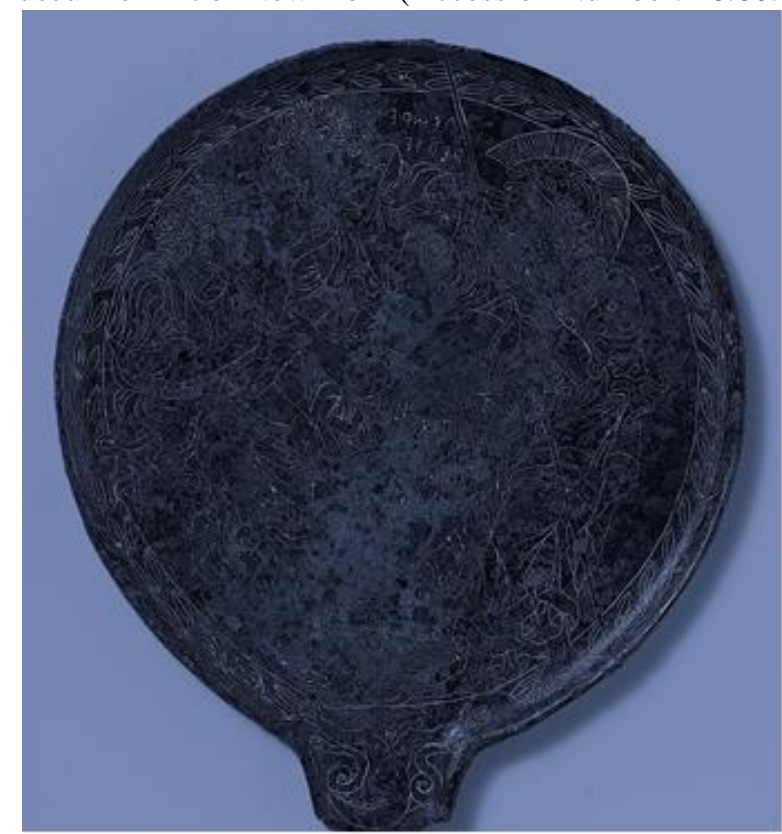

Figure 3. Etruscan mirror from the original Castellani Collection. Dated c. 400-350 BCE. Excavated in 1872 by Frattini in Palestrina. Inscribed in Etruscan: Enie (Enyo), Pemphetru (Pemphedo), Pherse (Perseus) and Menarea (Athena).

Note that these two representations are very late in relation 
to the time of Hesiod. Interestingly, the fragment of Fig. 1 shows only one of the Graeae and we do not know how many were present in the original object. In Figs. 2 and 3 only two Graeae appear. Note that in Figs. 2 and 3 Athena and not Perseus is taking the tooth from Pemphetru. For more pictorial representations of the Graeae see ${ }^{[12]}$. In Oakley's paper Figs. 2 and 4 (Attic red-figure column-krater stored in the Metaponto Antiquarium, No. 20145, found in Pisticci in Lucania, dated c. 460 BCE) show three Graeae ${ }^{[12]}$.

\section{REMARKS}

I am a fanatic of the science-fiction and fantastic literatures, in written form, from the 1950s until today (Asimov, Tolkien, Bradbury, Heinlein, Clarke, One Thousand and One Nights, etc.). From the times of the original Jason and the Argonauts (1963) and Clash of the Titans (1981) films, I added movies (many of them with adulterations) to my list. I tried to remember all I read and watched and, surprisingly, there is no book or film that contains such a brilliant idea as the Graeae. It is really astonishing that almost no one has written or speculated about them because no other similar or analogous history is known in Antiquity (or elsewhere as far as I know).

Therefore, here is a list of my questions regarding the Graeae and some remarks.

Who had this idea first? About the first man having the idea of joining the Graeae as two interdependent beings, we know nothing. Regarding the "when", it was before 750 and $650 \mathrm{BCE}$, but there is no archeological evidence allowing an earlier date to be proposed. It is tempting to suggest that it could be Hesiod but there is no basis supporting this statement. Unhappily, Hesiod's description of the Graeae is short and does not provide their features. Therefore, and this is very important, we do not know exactly if the shared eye and tooth attributes existed in Hesiod's time or were added later. Strictly speaking, from Hesiod's description almost nothing can be said about their attributes. Nevertheless, there is a point that nobody seems to have explored: their names. Why are they called "horror", "waster of cities, "alarm"? These names seem to be associated with war and/or plagues. We know nothing about possible plagues in the Bronze Age (nobody has investigated human remains looking for this possibility), but we know that Enyo appears in the Trojan War (the sack of Troy VIIa by the Greeks was $c .1183$ BCE, which coincides with the collapse of the Bronze Age) as a goddess of war. About Pephredo, nothing is known. Perhaps their names bear some earlier historical knowledge that is unknown to us. Summarizing: an open question.

Let us assume that the Graeae shared, at Hesiod's time, one eye and one tooth. What was the creator of this interlocked pair trying to communicate? Why were they only two at the beginning? To associate them with "either the rising moon and setting moon, or that luminary as successively crescent and gibbous" as Brown suggests is baseless. Our ancestors knew the phases of the moon very well since very long ago (for example the bone plate about $30 \mathrm{kyr}$ old from Abri Blanchard, the brown horse and a lunar calendar in Lascaux, dated $15 \mathrm{kyr}$, the astronomical knowledge of the Babylonians, etc.). However disastrous the collapse of the
Bronze Age and the Dark Ages may have been, there was no need for such a simple representation of the lunar phases. Moreover, there is no clear reason for inserting such a representation in Perseus' Journey. I think that the central point is another one.

First of all, the Graeae were not permanently blind: when one of them was using the eye and the tooth, she was able to see and eat, while the other one remained blind and unable to eat. Therefore, inclusion of the Graeae together with Phineus (the blind seer, King of Thrace, who revealed to Jason the location of Colchis in exchange for his release from the Harpies), or with Tiresias (the blind prophet of Apollo in Thebes, who was visited in the underworld by Odysseus to whom he gave valued information regarding the rest of his odyssey) can be done accepting that blindness gives access to new knowledge in some individuals. This leads to the question of why some individuals? Note that Phineus and Tiresias were blinded as a punishment and therefore it seems difficult to place the Graeae with them. Moreover, the Graeae were forced to release information making both temporarily blind at the same time. It is tempting to associate them with the idea of opposites, for which there are examples of rhetorical use as far back as Homer. But, what kind of opposites? For example, we may propose that the two Graeae represented the two states of consciousness (the "normal" and the "altered", but note that these two terms are intensionally vague up to the present day) of the Shamans, the Pythia, etc. This possibility can be ruled out because both Graeae were blinded at the same time by Perseus. Also, we may suggest that this blind state could be associated with a type of awareness-release or a state in which perception and feeling cease (something like Sūnyatā), but nothing is known about the collection of shared knowledge possessed by the Proto-Indo-Europeans. Notice also that the Graeae can be considered as being "the key": without them Perseus cannot follow his Journey. These are new open questions. Another possibility is that the shared eye and tooth attributes were added later. The same analysis just presented also holds for this possibility.

Why does their number increase to three? With the change of their number from two to three, either the original meaning was lost or somebody discovered new knowledge allowing to employ the Graeae retaining their original meaning but changing their number. As their original meaning is not known both possible answers are open to discussion. Let us note that, in her original form, Hecate ("Will") was represented holding two torches or one key ("Key" and "Will" are terms associated in several ways in Alchemy \& Esoterism). Some of her names or epithets are "bringing or bearing light", "before the gate", "holding the keys" and "on the way". Later she was depicted in triple form. Charles Perry provides us with very long list of interesting examples in which the number 3 is involved (he forgets to mention the Trimūrti of Hinduism and numerous similar examples) ${ }^{[15]}$. He stated that "But I trust that I have at least further convinced you that there is something quite singular and definitely special about the number three". Concerning Greece, Perry's list is quite impressive. But, regarding our topic, we face an interesting problem: the original Graeae 
were only two. And, if we consider the two primitive Graeae to be "the key" (or the bottleneck) in Perseus' Journey, then they can be assimilated (not equated!) to the original Hecate.

In summary, and fighting against intellectual laziness, I propose new questions and some possible answers regarding the Graeae. Most of these answers are only tentative and some questions remain unanswered today. I understand the need for new discoveries containing inscriptions and/or pictorial representations of the Graeae (or a full revision of all the available material in numerous museums). My hope is that one day somebody will discover an ancient Greek papyrus roll, like the Derveni papyrus, providing a new understanding of these enigmatic beings.

\section{REFERENCES}

[1] Hésiode; Salmon (Tr.), C.-A. Les Travaux et les jours. Hachette et Cie.: Paris, 1863.

[2] Hartland, E. S. The legend of Perseus: a study of tradition in story custom and belief (3 Vols.). D. Nutt: London, 1894.

[3] Brown, L. P. The Cosmic Teeth. The Open Court 1930, XLIV, 1-20.

[4] Hesiod; Most (Tr.), G. W. Hesiod Volume I. Theogony. Works and Days. Testimonia. Harvard University Press: Cambridge, Mass., 2006.

[5] Angier, C. Verbal Patterns in Hesiod's Theogony. Harvard Studies in Classical Philology 1964, 68, 329-344.

[6] Aeschylus; Case (Tr.), J. The Prometheus bound. J. M. Dent \& Sons: London, 1922.

[7] Apollodorus; Frazer (Tr.), J. G. The Library (2 Vols.). G. P. Putnam's Sons: London, 1921.

[8] Lemnos, P. d.; Vigenère (Tr.), B. d. Les Images ou Tableaux de platte peinture des deux Philostrates sophistes grecs et les Statues de Callistrate. Abel L'Angelier: Paris, 1615.

[9] Conti, N.; Baudoin, J.; Montlyard (Tr.), J. d.; Rabel (Gr.), D. Mythologie, ou Explication des fables, oeuvre d'eminente doctrine, \& d'agreable lecture. Cy-devant traduite par J. de Montlyard. Exactement reveüe en cette dernière édition, \& augmentée d'un Traitté des Muses; de plusieurs remarques fort curieuses; de diverses moralitez touchant les principaux dieux; et d'un Abbrégé de leurs images. Chez Pierre Chevalier, rüe S. Jacques à l'Image S. Pierre, près les Mathurins, et Samuel Thiboust, au Palais en la gallerie des prisonniers: Paris, 1627.

[10] Ogden, D. Perseus. Routledge: London, 2008.

[11] 11. Juigné Broissinière (sieur de Mollières), D. de Dictionnaire théologique, historique, poétique et cosmographique. 1. G. Le Bé \& J. Roger: Paris, 1644.

[12] Oakley, J. H. Perseus, the Graiai, and Aeschylus' Phorkides. American Journal of Archaeology 1988, 92, 383-391.

[13] Beazley, J. D. The Rosi Krater. The Journal of Hellenic Studies 1947, 67, 1-9.

[14] Anon. Collection Alessandro Castellani. Paris, 1884.

[15] Perry, C. D. The Tyranny of Three. The Classical Journal 1972, 68, 144-148.

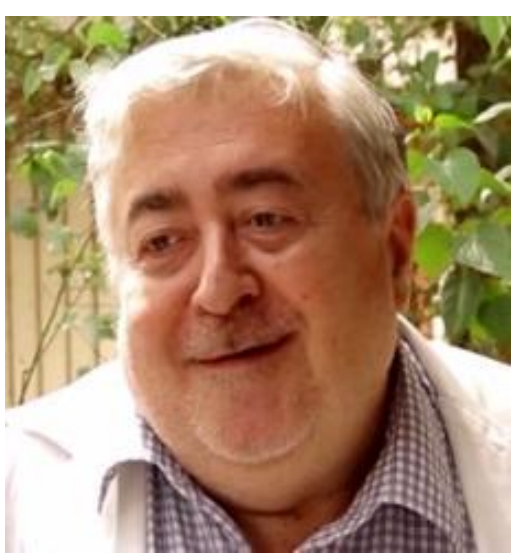

Dr. Juan Sebastián Gómez-Jeria. Graduate in Chemistry and Chemist at the University of Chile, $\mathrm{PhD}$ in Molecular Physical Chemistry (UNAB). Research in Quantitative Structure-Activity relationships, electronic structure of nanostructures and philosophy of science. Lecturer in Quantum Chemistry and Quantum Pharmacology, History and Philosophy of Science. In charge of Physical Chemistry teaching Labs. He has published three books and more than 150 papers. 